Саюк О. А., кандидат сільськогосподарських наук, Трояченко Р. М., здобувач вищої освіти ступеня доктора філософії, Павлюк І. О., здобувач наукового ступеня кандидата наук Житомирський національний агроекологічний університет

\title{
ВИДОВИЙ СКЛАД БУР'ЯНОВОГО КОМПОНЕНТУ АГРОЦЕНОЗУ КАРТОПЛІ
}

\author{
Рецензент - кандидат сільськогосподарських наук Т. В. Клименко
}

Мета статті - дослідження видового та кількісного складу бур'янового компоненту агроченозу картоплі в умовах Черняхівського району Житомирської області.

Методика дослідження. У процесі дослідження використано такі наукові методи: аналізу і синтезу (визначення фактичної забур'яненості насаджень картоплі, видового складу бур'янів); теоретичний пошук і абстрактно-логічний (теоретичні узагальнення та формулювання висновків); графічний (відображення результатів дослідження графічно).

Результати дослідження. У статті наведено результати дослідження щзодо вивчення видового складу бур'янового компонента агроченозу картоплі та його розвитку протягом вегетаиії культури. Дослідження проводили шляхом кількісного підрахунку чисельності бур'янів протягом вегетації картоплі та визначення їх видового складу. Встановлено, щзо бур'янова синузія насаджень картоплі представлена однорічними пізніми ярими видами (63,2\%). Протягом вегетачії рослин картоплі спо-

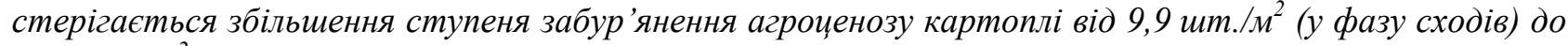

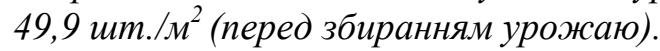

Елементи наукової новизни. Встановлено видовий та кількісний склад бур'янового компоненту агроценозу картоплі та його розвиток протягом вегетачії культури.

Практична значущість. Знання видового складу бур'янів у насадженнях картоплі, терміни появи їх сходів, кількісний склад досліджуваного шкідливого організму дасть змогу використати найбільш ефективні заходи регулювання чисельності бур'янів з метою отримання максимального врожаю.

Ключові слова: картопля, бур 'яни, ступінь забур 'яненості, вид, агроценоз.

Саюк Олександр Анатолійович - кандидат сільськогосподарських наук, доцент, декан агрономічного факультету, Житомирський національний агроекологічний університет, Старий Бульвар, 7 , м. Житомир, 10002, Україна, e-mail: oasayuk1@gmail.com, ORCID ID: 0000-0002-1355-0832.

Трояченко Руслан Миколайович - здобувач вищої освіти ступеня доктора філософії кафедри технології зберігання та переробки продукції рослинництва, Житомирський національний агроекологічний університет, Старий Бульвар, 7, м. Житомир, 10002, Україна, e-mail: zherm@ukr.net.

Павлюк Ірина Олександрівна - здобувач наукового ступеня кандидата наук кафедри технології зберігання та переробки продукції рослинництва, Житомирський національний агроекологічний університет, Старий Бульвар, 7, м. Житомир, 10002, Україна, e-mail: irapaw@ukr.net.

Постановка проблеми. Одним із найбільш негативних факторів впливу на урожайність i якість сільськогосподарських культур $є$ забур'яненість посівів. Бур'яни входять до складу агрофітоценозу і стають конкурентами культурним рослинам у боротьбі за елементи живлення. Втрати від забур'яненості посівів значною мірою залежать від фази розвитку культурних рослин, коли вони вступають у конкурентну боротьбу з бур'янами. Відсутність вчасно проведених захисних заходів може призвести до повної загибелі культурного компоненту агроценозу $[2,9,11]$.

Існують загальні дані, що середньорічні світові втрати від бур'янів урожаю зерна пшениці озимої становлять $24 \%$, кукурудзи - $29 \%$, цук- рових буряків - $37 \%$ і картоплі - $23 \%$. Це, насамперед, результат гострої конкуренції бур'янів 3 культурними рослинами за основні фактори життя $[2,8]$.

Пристосовуючись до життя культурних рослин, бур'яни набувають аналогічних їм властивостей. Як вищі форми рослин, вони мають високу екологічну пластичність. На сільськогосподарських угіддях культурні рослини і бур'яни ростуть разом і формують агрофітоценози, у яких, завдяки винятковій життєздатності бур'янів, зберігається їх стійкість у конкурентній боротьбі. Сформовані у процесі багатовікової історії розвитку сучасні популяції бур'янів набули властивостей, які допомагають їм протистояти інтенсивному антропогенному 


\section{СІЛЬСЬКЕ ГОСПОДАРСТВО. РОСЛИННИЦТВО}

впливу [6, 9, 12].

Наявність бур'янів в агроценозі картоплі також спричиняє негативний вплив на урожайність та якість бульб. Крім того, бур'яни є джерелом поширення збудників різних хвороб і осередком розмноження шкідників, зокрема, збудник раку картоплі (Synchytrium endobioticum Percival.) переноситься на цю культуру із пасльону чорного (Solanum nigrum L.). Також засмічені бур'янами насадження картоплі погано провітрюються, i тим самим створюються умови для розвитку збудника фітофторозу (Phytophthora infestans (Mont) de Bary). Підземні гострі пагони пирію повзучого (Elytrigia repens L.) вростають у молоді бульби, механічно їх пошкоджують, позбавляють товарного вигляду і якості $[8,9,11]$.

Повністю знищити бур'яни неможливо, але зменшити їх чисельність та завдану ними шкоду до практично незначної величини - завдання вчених та практиків сільськогосподарського виробництва. Моніторинг стану посів картоплі щодо визначення фактичної забур'яненості та вчасне проведення захисних заходів дає можливість мінімізувати втрати в урожайності та якості бульб $[3,11]$.

Аналіз останніх досліджень і публікацій, у яких започатковано розв'язання цісї проблеми. Природно-кліматичні умови нашої країни $\epsilon$ досить сприятливими для розвитку картоплі та дозволяють вирощувати іiі практично на всій території. Проте, як і в інших агроценозах сільськогосподарських культур, у насадженнях картоплі зростає та спричиняє негативний вплив значна кількість бур'янів. У картоплі є досить тривалим період від посадки до появи сходів, протягом якого встигає зійти і вкорінитися значна кількість бур'янів. Бур'яни стають не лише конкурентами картоплі за світло, вологу та поживні речовини, але й накопичувачами різного роду шкідливих організмів. У насадженнях картоплі найбільш поширеними бур'янами є щириця звичайна (Amaranthus retroflexus L.), лобода біла (Chenopodium album L.), редька дика (Raphanus raphanistrum L.), різні види осотів (Sonchus), берізка польова (Convolvulus arvensis L.), пирій повзучий (Elytrigia repens L.), галінсога дрібноквіткова (Galinsoga parviflora Cav.), тощо. Протягом останніх років у посівах сільськогосподарських культур спостерігається поширення такого карантинного виду бур'яну як амброзія полинолиста (Ambrosia artemisiifolia L.), який, формуючи розвинену кореневу систему, призводить до надмірного висушування та виснаження грунту, зниження урожайності, а також спричиняє негативний вплив на здоров'я людини, викликаючи ма- сові алергічні захворювання $[3,10,11]$.

Без належного обліку забур'яненості насаджень картоплі проводити заходи щодо регулювання чисельності бур'янів у сучасних умовах господарювання практично неможливо. Необгрунтоване застосування агротехнічних, а тим більше хімічних заходів проти бур'янів, призводить до порушення екологічної рівноваги та підвищення затрат на одиницю вирощеної продукції тощо. Враховуючи, що картопля є одним із основних продуктів харчування, застосування гербіцидів при інтенсивних технологіях вирощування необхідне для кожного конкретного випадку із обов'язковим врахуванням кількісного та видового складу бур'янового компоненту в агроценозі картоплі, а також з урахуванням прогнозу забур'яненості та засміченості грунту насінням та вегетативними органами бур'янів $[3,10,12]$.

Саме тому, метою роботи було визначення видового та кількісного складу бур'янового компоненту в агроценозі картоплі.

Завдання дослідження: встановити фактичну забур'яненість та визначити видовий склад бур'янового компоненту насаджень картоплі.

Матеріали і методи досліджень. Дослідження проводилися впродовж 2017-2018 рр. в умовах ПП «Жерм» Черняхівського району Житомирської області. У дослідженнях використовували сорт картоплі Бела росса. Визначення фактичної забур'яненості насаджень картоплі здійснювали згідно із загальноприйнятими методиками. Загальний рівень забур'яненості насаджень картоплі визначали кількісним методом за п’ятибальною шкалою, де 1 бал - дуже слабкий ступінь забур'яненості (1-5 шт/м²), а 5 балів дуже сильний ступінь забур'яненості (понад 100 шт/м²). Видовий склад сегетальної рослинності у насадженнях картоплі визначали із використанням атласів-визначників $[1,4,5,7]$.

Математичну обробку одержаних результатів дослідження проводили за допомогою пакету дисперсійного аналізу даних програмного забезпечення «Excel» та «Statistica 7》.

Результати досліджень. У результаті проведених досліджень встановлено, що в умовах господарства у насадженнях картоплі сорту Бела росса переважає змішаний тип забур'яненості. Основне місце у структурі видового складу бур'янів у насадженнях картоплі належить однорічним видам, що становить 83,4 \% (див. рис.). Однорічні пізні ярі види бур'янів займають $63,2 \%$ у загальній бур'яновій синузії насаджень картоплі. Цей біологічний тип представлений такими видами як галінсога дрібноквітко- 


\section{СІЛЬСЬКЕ ГОСПОДАРСТВО. РОСЛИННИЦТВО}

ва (Galinsoga parviflora Cav.), щириця звичайна (Amaranthus retroflexus L.) та мишій сизий (Setaria glauca L.). $20,2 \% \quad$ у структурі забур'яненості насаджень картоплі представлено лободою білою (Chenopodium album L.) та гірчицею польовою (Sinapis arvensis L.), що відносяться до групи однорічних ранніх ярих. Частка багаторічних коренепаросткових бур'янів, які представлені осотом жовтим (Sonchus arvensisL.) та берізкою польовою (Convolvulus arvensis L.), становила $10,6 \%$ та 6,0 \% відповідно.

Проведені нами спостереження за термінами появи сходів бур'янів показали, що основна їхня кількість проростає у два етапи. Перший етап появи сходів бур'янів у насадженнях картоплі триває у період від посадки до появи сходів картоплі. У цей період 3'являються, в основному, сходи ранніх ярих видів, таких як лобода біла та гірчиця польова. Другий етап триває від фази повних сходів до початку змикання бадилля у рядках та представлений пізніми ярими та багаторічними видами бур'янів. Протягом цього етапу і практично до кінця вегетації культури нами відмічено розвиток у насадженнях картоплі сорту Бела росса таких видів бур'янів як галінсога дрібноквіткова, щириця звичайна, мишій сизий, берізка польова, осот жовтий. Урахування цього показника дасть змогу вчасно провести агротехнічні заходи, щоб не допустити розвитку бур'янів у насадженнях картоплі.

Протягом вегетації рослин картоплі нами було проведено обліки щодо визначення ступеня забур'яненості насаджень (див. табл.).

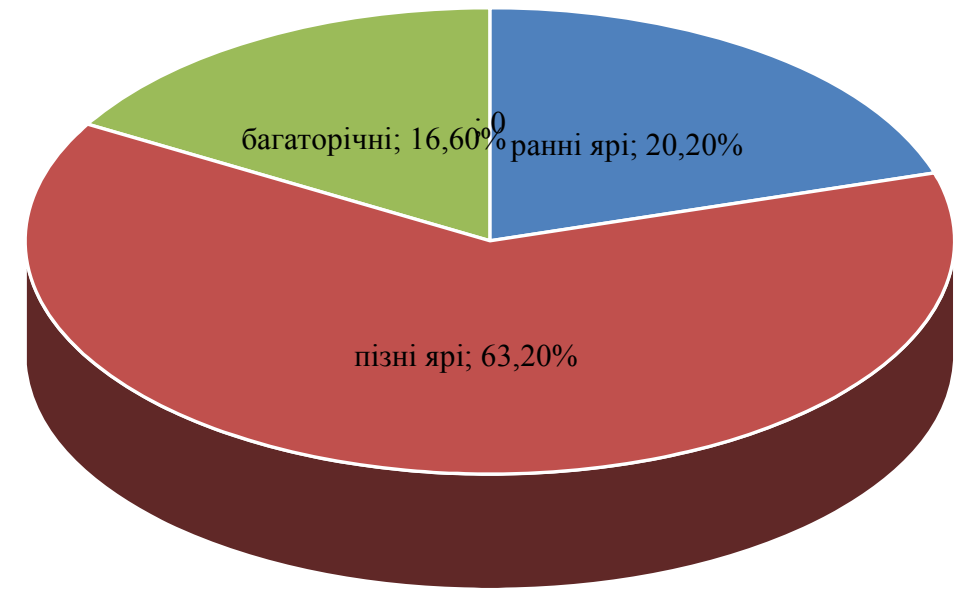

Рис. Структура бур'янової синузії в агроценозі картоплі

Джерело: авторські дослідження.

Фактична забур'яненість насаджень картоплі (2017-2018 рр.)

\begin{tabular}{|l|c|c|c|c|}
\hline \multirow{2}{*}{ Біологічний тип } & \multirow{2}{*}{ Вид бур'яну } & \multicolumn{3}{|c|}{ Кількість, шт./ ${ }^{2}$} \\
\cline { 3 - 5 } & сходи & бутонізація & $\begin{array}{c}\text { 3бирання вро- } \\
\text { жаю }\end{array}$ \\
\hline \multirow{2}{*}{ Однорічні ранні ярі } & Гірчиця польова & 1,2 & 1,8 & 2,1 \\
\hline \multirow{2}{*}{ Однорічні пізні ярі } & Лобода біла & 2,1 & 2,5 & 5,4 \\
\cline { 2 - 5 } & $\begin{array}{c}\text { Галінсога } \\
\text { дрібноквіткова }\end{array}$ & 2,7 & 7,5 & 14,7 \\
\cline { 2 - 5 } & Щириця звичайна & 2,1 & 5,6 & 7,2 \\
\cline { 2 - 5 } & Мишій сизий & 1,8 & 9,3 & 17,3 \\
\hline \multirow{2}{*}{$\begin{array}{l}\text { Багаторічні коренепарост- } \\
\text { кові }\end{array}$} & Берізка польова & - & 1,1 & 1,5 \\
\hline НІР $_{05}$ & Осот жовтий & - & 1,0 & 0,2 \\
\hline
\end{tabular}

Джерело: авторські дослідження. 
Виявлено, що найменша кількість бур'янів, що становить у середньому 9,9 шт./ м $^{2}$ формується у насадженнях картоплі у фазу сходів. У цей період починали сходити однорічні ранні ярі та пізні ярі види. У період бутонізації забур'яненість насаджень картоплі була на рівні 3 балів, що становило 28,8 шт./м². На час збирання врожаю картоплі забур'яненість посівів була найвищою і становила 49,9 шт./м². Дослідженнями встановлено, що протягом вегетації стабільно високою на одиницю обліку залишилися галінсога дрібноквіткова та мишій сизий, їхня кількість перед збиранням врожаю становила $14,7 \%$ та 17,3 \% відповідно.

\section{Висновки:}

1. У структурі бур'янової синузії агроценозу картоплі в умовах Черняхівського району

\section{БІБЛІОГРАФІЯ}

1. Атлас найбільш поширених бур'янів України / за ред. О. С. Мельничука, Г. М. Ковалівського. Київ : Урожай, 1972. 204 с.

2. Бур'яни та заходи боротьби з ними / Ю. П. Манько, І І. В. Веселовський, Л.В.Орел, С. П. Танчик. Київ : Учбово-метод. центр Мінагропрому України, 1998. 240 с.

3. Бурда Р. I. Концепція сучасної науки про сегетальні бур'яни. Агроекологічний журнал. 2002. № 1. C. 3-11

4. Васильченко И. Т. Определитель всходов сорных растений. Москва : Колос, 1979. 344 с.

5. Веселовський І. В., Лисенко А. К., Манько Ю. П. Атлас-визначник бур'янів. Київ : Урожай, 1988. $371 \mathrm{c}$.

6. Веселовський І. В., Манько Ю. П., Козубський О. Б. Довідник по бур'янах. Київ : Урожай, 1993. $208 \mathrm{c}$.

\section{REFERENCES}

1. Melnychuk, O. S., Kovalivskyi, H. M. (Ed.) (1976). Atlas naibilsh poshyrenykh bur'ianiv Ukrainy [Atlas of the most common weeds in Ukraine]. Kyiv: Urozhai [In Ukrainian].

2. Manko, Yu. P., Veselovskyi, I. V., Orel, L. V., Tanchyk, S. P. (1998). Bur'iany ta zakhody borotby $z$ nymy [Weeds and measures of control them]. Kyiv: Uchbovo-metod. tsentr Minahropromu Ukrainy [In Ukrainian].

3. Burda, R. I. (2002). Kontseptsiia suchasnoi nauky pro sehetalni bur'iany [Concept of modern science about seedlings weeds]. Ahroekolohichnyi zhurnal, 1, pp. 3-11 [In Ukrainian].

4. Vasylchenko, Y. T. (1979). Opredelytel vskhodov sornykh rastenyi [Determinant of shoots of weed plants]. Moskva: Kolos [In Russian].
Житомирської області переважають однорічні пізні ярі види.

2. Сходи бур'янів у насадженнях картоплі 3'являються у два етапи: перший - від посадки до появи сходів культури, другий - від фази повних сходів до початку змикання бадилля у рядках.

3. Ступінь забур'янення агроценозу картоплі підвищується протягом вегетації культури: від

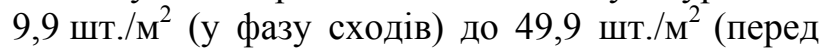
збиранням урожаю).

Перспективи подальшої роботи в цьому напрямі. Перспективами подальших досліджень $\epsilon$ моніторинг насаджень картоплі щодо визначення фактичної і потенційної забур'яненості посівів та пошук ефективних заходів регулювання чисельності бур'янів в агроценозі картоплі.

7. Грицаєнко 3. М., Грицаєнко А. О., Карпенко В. П. Методи біологічних та агрохімічних досліджень рослин і грунтів. Київ : ЗАТ «НІЧЛАВА», 2003. $320 \mathrm{c}$.

8. Зуза В.С. Вредоносность сорняков в посевах различных сельскохозяйственных культур. Захист рослин. 1995. Вип. 42. С. 43-48.

9. Іващенко О. О. Бур'яни в агрофітоценозах. Київ : «Світ», 2001. 234 с.

10. Манько Ю.П. Прогнозування забур'яненості полів та еколого-економічне обгрунтування заходів захисту посівів від бур'янів. Київ : Вид-во УСГА, 1992. 18 с.

11. Фисюнов А. В. Сорные растения. Москва : Колос, 1984. 320 с.

12. Шувар I. А. Екологічні основи зниження забур'яненості агрофітоценозів. Львів : Новий Світ-2000, 2008. 494 с.

5. Veselovskyi, I. V., Lysenko, A. K., Manko, Yu. P. (1988). Atlas-vyznachnyk bur'ianiv [Atlasdeterminant of weeds]. Kyiv: Urozhai [In Ukrainian].

6. Veselovskyi, I. V., Manko, Yu. P., Kozubskyi, O. B. (1993). Dovidnyk po bur'ianakh [Weed reference book]. Kyiv: Urozhai [In Ukrainian].

7. Hrytsaienko, Z. M., Hrytsaienko, A. O., Karpenko, V. P. (2003). Metody biolohichnykh ta ahrokhimichnykh doslidzhen roslyn i gruntiv [Methods of biological and agrochemical studies of plants and soils]. Kyiv: ZAT «NIChLAVA» [In Ukrainian].

8. Zuza, V. S. (1995). Vredonosnost sorniakov $\mathrm{v}$ posevakh razlychnykh selskokhoziaistvennykh kultur [Infestation of weeds in crops of various 
crops]. Zakhyst roslyn, 42, pp. 43-48 [In Ukrainian].

9. Ivashchenko, O. O. (2001). Bur'iany $v$ ahrofitotsenozakh [Weed in agrophytocenoses]. Kyiv: «Svit» [In Ukrainian].

10. Manko, Yu. P. (1992). Prohnozuvannia zabur'ianenosti poliv ta ekoloho-ekonomichne obgruntuvannia zakhodiv zakhystu posiviv vid bur'ianiv [Forecasting of field irritation and ecological and economic substantiation of measures of protection of crops from weeds]. Kyiv: Vyd-vo USHA [In Ukrainian].

11. Fysiunov, A. V. (1984). Sornye rastenyia [Weed plants]. Moskva: Kolos [In Russian].

12. Shuvar, I. A. (2008). Ekolohichni osnovy znyzhennia zabur'ianenosti ahrofitotsenoziv [Ecological bases of reduction of weedness of agrophytocenoses]. Lviv: Novyi Svit-2000 [In Ukrainian].

Саюк А. А., Трояченко Р. Н., Павлюк И. А. Видовой состав сорного компонента агроценоза картофеля

Цель статьи - исследование видового и количественного состава сорного компонента агроченоза картофеля в условиях Черняховского района Житомирской области.

Методика исследования. В прочессе исследования использованы следующие научные методы: анализа и синтеза (определение фактической засоренности насаждений картофеля, видового состава сорняков); теоретический поиск и абстрактно-логический (теоретические обобщения и формулирования выводов); графический (отображение результатов исследования графически).

Результаты исследования. В статье приведены результаты исследования по изучению видового состава сорного компонента агроценоза картофеля и его развития в течение вегетации культуры. Исследования проводились путем количественного подсчета численности сорняков в период вегетаuии картофеля и определения их видового состава. Установлено, что сорный компонент насаждений картофеля представлен однолетними поздними яровыми видами (63,2%). В течение вегетации растений картофеля наблюдается увеличение степени засоренности агроценоза картофеля от

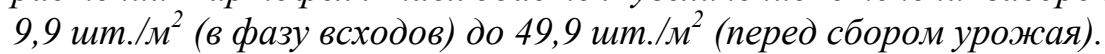

Элементы научной новизны. Установлено видовой и количественный состав сорного компонента агроценоза картофеля и его развитие в течение вегетачии культуры.

Практическая значимость. Знание видового состава сорняков в посадках картофеля, сроки появления их всходов, количественный состав исследуемого вредоносного организма позволит применять наиболее эффективные меры регулирования численности сорняков с иелью получения максимального урожая.

Ключевые слова: картофель, сорняки, степень засоренности, вид, агроценоз.

Саюк Александр Анатольевич - кандидат сельскохозяйственных наук, доцент, декан агрономического факультета, Житомирский национальный агроэкологический университет, Старый Бульвар, 7, г. Житомир, 10002, Украина, e-mail: oasayuk1@gmail.com, ORCID ID: 0000-0002-1355-0832.

Трояченко Руслан Николаевич - соискатель высшего образования степени доктора философии кафедры технологии хранения и переработки продукции растениеводства, Житомирский национальный агроэкологический университет, Старый Бульвар, 7, г. Житомир, 10002, Украина, e-mail: zherm@ukr.net.

Павлюк Ирина Александровна - соискатель ученой степени кандидата наук кафедры технологии хранения и переработки продукции растениеводства, Житомирский национальный агроэкологический университет, Старый Бульвар, 7, г. Житомир, 10002, Украина, e-mail: irapaw@ukr.net.

\section{Saiuk O. A., Troiachenko R. M., Pavliuk I. O. Species composition of the weed component of potato} agrocenosis

The purpose of the article is studying species and quantity composition of the weed component of potato agrocenosis in the conditions of Cherniakhivskyi district of Zhytomyr region.

Methods of research. In the process of the research, the following scientific methods were used: analysis and synthesis (determining the actual weed infestation of potato plantings, species composition of weeds); theoretical search and abstract-logical (theoretical generalizations and formulation of conclusions); graphic (reflecting the research results graphically).

The research results. The research results as to the species composition of the weed component of potato agrocenosis and its development during the crop vegetation period have been presented in the article. The 
research has been carried out by quantitative calculating the number of weeds during potato vegetation and determining their species composition. It has been established that weed synusia of potato plantings are represented by annual late spring species (63.2\%). During potato plants vegetation, the increase in the degree of weed infestation of potato agrocenosis from $9.9 \mathrm{pcs} . \mathrm{m}^{2}$ (in the phase of sprouts) to $49.9 \mathrm{pcs} . \mathrm{m}^{2}$ (before harvesting) has been observed.

The elements of scientific novelty. The species and quantity composition of the weed component of potato agrocenosis and its development during the crop vegetation has been established.

Practical significance. The knowledge of the species weed composition on potato plantations, the terms of their germination, the quantitative composition of the studied harmful organism will make it possible to use the most effective measures to regulate the number of weeds in order to obtain maximal yield.

Key words: potatoes, weeds, degree of weed infestation, species, agrocenosis.

Saiuk Oleksandr Anatoliiovych - Candidate (PhD) of Agricultural Sciences, Associate Professor, Dean of the Faculty of Agronomy, Zhytomyr National Agro-Ecological University, 7, Staryi Bulvar, Zhytomyr, 10002, Ukraine, e-mail: oasayuk1@gmail.com, ORCID ID: 0000-0002-1355-0832.

Troiachenko Ruslan Mykolaiovych - applicant for PhD scientific degree of the Department of Plant Products Storage and Processing Technologies, Zhytomyr National Agro-Ecological University, 7, Staryi Bulvar, Zhytomyr, 10002, Ukraine, E-mail: zherm@ukr.net.

Pavliuk Iryna Oleksandrivna - applicant for PhD scientific degree of the Department of Plant Products Storage and Processing Technologies, Zhytomyr National Agro-Ecological University, 7, Staryi Bulvar, Zhytomyr, 10002, Ukraine, e-mail: irapaw@ukr.net.

Стаття надійшла до редакції 28.02.2019 р.

Бібліографічний опис для цитування :

Саюк О. А., Трояченко Р. М., Павлюк I. О. Видовий склад бур'янового компоненту агроценозу картоплі. Вісник ПДАА. 2019. № 1. С. 35-40.

DOI 10.31210/visnyk2019.01.04

(c) Саюк Олександр Анатолійович, Трояченко Руслан Миколайович, Павлюк Ірина Олександрівна, 2019 